\title{
Article
}

\section{The Influence of the COVID-19 Pandemic on the Stress Levels and Occurrence of Stomatoghnatic System Disorders (SSDs) among Physiotherapy Students in Poland}

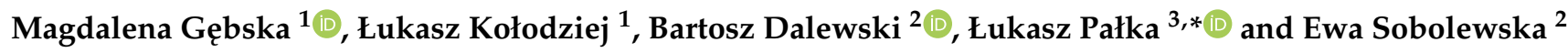 \\ 1 Department of Rehabilitation Musculoskeletal System, Pomeranian Medical University, \\ 70-204 Szczecin, Poland; mgebska@pum.edu.pl (M.G.); lukas@hot.pl (Ł.K.) \\ 2 Department of Dental Prosthetics, Pomeranian Medical University, 70-204 Szczecin, Poland; \\ bartosz.dalewski@pum.edu.pl (B.D.); rpsobolewski@wp.pl (E.S.) \\ 3 Private Dental Practice, 68-200 Żary, Poland \\ * Correspondence: dr.lpalka@gmail.com; Tel.: +48-608882535
}

check for updates

Citation: Gẹbska, M.; Kołodziej, Ł.; Dalewski, B.; Pałka, Ł.; Sobolewska, E. The Influence of the COVID-19

Pandemic on the Stress Levels and Occurrence of Stomatoghnatic System Disorders (SSDs) among Physiotherapy Students in Poland. J. Clin. Med. 2021, 10, 3872. https:// doi.org/10.3390/jcm10173872

Academic Editor: Michele Roccella

Received: 2 July 2021

Accepted: 27 August 2021

Published: 28 August 2021

Publisher's Note: MDPI stays neutral with regard to jurisdictional claims in published maps and institutional affiliations.

Copyright: (c) 2021 by the authors. Licensee MDPI, Basel, Switzerland. This article is an open access article distributed under the terms and conditions of the Creative Commons Attribution (CC BY) license (https:/ / creativecommons.org/licenses/by/ $4.0 /)$.

\begin{abstract}
Background: This study is a quantitative analysis examining the impact of the COVID-19 pandemic on the occurrence of stress and stomatognathic system disorders (SSDs) among students of physiotherapy. Objective: To assess stress severity, strategies of coping with stress and the presence of type D personality among physiotherapy students including those with symptoms of stomatognathic system disorders. Material and Methods: The research was conducted from October to December 2020 on a sample of 188 students of physiotherapy. The data were collected using a survey form related to the occurrence of SS disorders symptoms and standardized psychological questionnaires, such as the Perceived Stress Scale (PSS)-10, Mini-Cope, and the type-D Scale (DS14), developed for the purpose of this study. Results: Women experiencing at least one of the SS disorder-related symptoms were characterized by a significantly higher level of stress and a type D personality $(p<0.05)$. Among men, these differences were not statistically significant $(p>0.05)$. On the basis of the strategies of coping with stress, i.e., positive self-reevaluation, discharging and blaming oneself, and taking psychoactive substances, it is possible to predict the intensity of stress during the pandemic in the group of the examined students. Among the reported symptoms of SS, headache was a significant predictor of stress, which was accompanied by an increase in the intensity of stress by nearly 0.2 measurement points. Students with higher levels of stress showed more symptoms of type D personality, and those with more severe symptoms of SS showed higher levels of stress. Conclusions: People prone to stress and having type D personality traits should be assessed for the presence of SS disorders.
\end{abstract}

Keywords: COVID-19; stress; stomatognathic system; students

\section{Introduction}

The SARS-CoV-2 pandemic has significantly impacted the mental health of populations around the world [1]. As the pandemic-related threat developed, people were forced to change their lifestyle [1]. The economy and its mechanisms, tourism industry, the functioning of culture, and teaching methods at all levels of education have been transformed [1,2]. At medical universities in Poland, necessary recommendations were introduced, i.e., hybrid teaching, limited social and professional contacts, as well as restricted access to university hospitals. As medical college education is largely based on practical skills, students became concerned about their development. Moreover, the uncertainty accompanying senior-year students as to how to fill in the gaps in education could have influenced the level of stress they felt. The pandemic also had a negative impact on attention span and enhanced learning difficulties, which resulted in increased concerns about final exam results. 
Social isolation resulting from the pandemic, fear for oneself and loved ones, and financial instability also had a negative impact on the psychophysical health of students. The everyday uncertainty created an environment of anxiety and depression, and the quarantines contributed to a loss of social ties, deepening the feeling of loneliness or anger [3]. These stress factors could lead to the development of health problems associated with the whole body. Psychological factors, especially stress and the ability to deal with it, play a significant role in the etiology of stomatognathic system disorders (SSDs). Coping with lockdown measures was also associated with increased alcohol intake in men $[4,5]$.

Stress that accompanies our daily lives contributes not only to cardiovascular, digestive, and respiratory diseases, but also increases muscle tone of the SS. As a consequence, symptoms such as: bruxism, pain in the temporomandibular joints (TMJs), and headaches may appear. Long-term symptoms of SSDs may contribute to irreversible changes in this system, resulting in impaired chewing, swallowing, speech, and breathing functions [6-20]. Additionally, long-term reports about TMJ internal derangements were released [21-25]. Hypothalamus, limbic system and reticular formation are responsible for psychological processes in humans [26]. These centers, through gamma-efferent fibers, which supply the muscle spindles, influence the myogenic activity of the body. In long-term stressful situations, they cause an increase in muscle tonus, also in the facial part of the skull, contributing to the formation of myogenic dysfunctions of the SS [5].

In 1926, Hans Hugon Selye introduced the concept of stress to health sciences. In medical terms, it is defined as a disorder of the body's homeostasis caused by physical or psychological elements [6-8]. It can be caused by mental, physiological, anatomical [7,8], or physical factors [9-11,14]. Stressful situations lead to increased muscle tension, which is the body's natural response to threat. SS muscles, like other skeletal muscles in the human body, can react with increased tension, pain, and/or hypertrophy when strained [7].

People react differently to stressors, which may depend on the personality type of the individual [27]. At the end of the 1990s, the concept of distressed personality (type D) was introduced into the literature, which resulted in an increased interest in the problem of the relationship between personality and somatic diseases [28]. Type D consists of two main dimensions-negative affectivity and social inhibition. Negative emotionality is expressed as a tendency to experience strong negative emotions such as fear, anger, irritation, and hostility. On the other hand, social inhibition is associated with the tendency to refrain from expressing negative emotions and behavior consistent with these emotions. People with type $\mathrm{D}$ personalities tend to be worried, tense, and blamed [29]. They are characterized by a pessimistic way of looking at the world, low self-esteem, and low level of satisfaction with life [30]. Type D personality has been found to be a significant predictor of cardiovascular disease, gastric and duodenal ulcer, and skin diseases [31-34].

Medical college students may be particularly prone to the negative effects of the pandemic. This study is a quantitative analysis examining the impact of the psychological effects of the pandemic on the occurrence of stress and stomatognathic system disorders among students of physiotherapy. The results of this research may help in preparing appropriate future intervention programs and effective prevention strategies in crisis situations at universities [32,35-38].

The aim of this study was to assess stress severity, coping with stress strategies, and the presence of type $\mathrm{D}$ personality in students with symptomatic stomatognathic system disorders. We hypothesized that stress, the ability to cope with it, and the type D personality may influence the development of SS disorders.

\section{Materials and Methods}

The research was conducted from October to December 2020 among randomly selected students of physiotherapy at the Pomeranian Medical University in Szczecin. The sample consisted of 188 participants ( 125 female and 63 male) aged 20 to 35 years (mean =22.72). All participants agreed to voluntarily participate in the study by signing an informed consent. They were asked to fill in the survey consisting of two parts: the first part 
included a respondent's particulars (age, sex, year of study) and ten close-ended questions concerning the symptoms of SSDs and pain (Likert scale) [39-45]. The second part consisted of standardized psychological questionnaires, PSS10 (perceived stress scale), Mini-Cope (Inventory for measuring coping with stress), DS14 (Type-D scale) [46-54]. As a result of the activities performed, 150 participants (study group-P1) with SSD symptoms and pain were selected from the group. The remaining 38 participants who did not report any symptoms from SSD were enrolled into the control group P2.

The sample size was calculated based on the data on a specific population (finite population) and the formula for the minimum sample size was as follows:

$$
N_{\text {min }}=\frac{P(\mathbf{1}-\boldsymbol{P})}{\frac{e^{2}}{Z^{2}}+\frac{P(\mathbf{1}-\boldsymbol{P})^{\prime}}{N}}
$$

where:

$P$-estimated fraction size,

$Z$ - value resulting from the adopted significance level $(\alpha)$, calculated using the cumulative distribution function of the normal distribution,

$\mathrm{N}$-size of the general population (in the case of a finite population),

$e$-maximum estimation error.

After entering the data, namely:

$P-50 \%$

Z-1\% (0.01)

$N-8017$

e- $-10 \%$

The finite population sample size equaled: 163

The inclusion and exclusion criteria were as follows:

Inclusion criteria:

- $\quad 1$ st or 2nd year student of physiotherapy learning in a hybrid system (stationary and remote),

- reported symptoms of US disorders (from 6 months),

- age: $20-35$,

- a written consent to participate in the study.

Exclusion criteria:

- chronic diseases, including psychosomatic,

- people during or after the treatment of SS disorders,

- pregnancy.

The differentiating factor between the study group (P1) and the control group (P2) was the lack of symptoms of SS disorders in the control group.

Among 1st and 2nd year students of physiotherapy who met the inclusion and exclusion criteria, the study group (P1) and participants without symptoms of SSD (P2) were selected on the basis of the SSD symptom questionnaire.

The main goal of the present study was to compare the groups that are as homogeneous as possible in terms of everyday functioning and exposure to stressful situations while studying during the pandemic. Therefore, a small sample size resulted from the limited number of physiotherapy students.

\subsection{Characteristics of the Studied Group}

Table 1 contains information on the frequency of reported individual symptoms and the average intensity of pain. Descriptive statistics for the entire group and separate statistics for the P1 and P2 subgroups are given. The statistical comparison of these two groups was abandoned due to the lack of occurrence of the studied variables in the P2 group. 
Table 1. Characteristics of the study group in terms of experienced SS symptoms.

\begin{tabular}{|c|c|c|c|}
\hline Pain in the Region: & Whole Group, $n=188$ & $\mathrm{P} 1, n=150$ & $\mathrm{P} 2, n=38$ \\
\hline \multicolumn{4}{|l|}{ Temporomandibular pain } \\
\hline Occurrence * & $27(14.4 \%)$ & $27(18.0 \%)$ & $0(0.0 \%)$ \\
\hline Intensity $* *$ & $0.32(0.82)$ & $0.39(0.90)$ & - \\
\hline \multicolumn{4}{|l|}{ Headache } \\
\hline Occurrence & $102(54.3 \%)$ & $102(68.0 \%)$ & $0(0.0 \%)$ \\
\hline Intensity & $1.39(1.45)$ & $1.73(1.43)$ & - \\
\hline \multicolumn{4}{|c|}{ Pain in the neck and pectoral girdle } \\
\hline Occurrence & $87(46.3 \%)$ & $87(58.0 \%)$ & $0(0.0 \%)$ \\
\hline Intensity & $1.13(1.35)$ & $1.38(136)$ & - \\
\hline \multicolumn{4}{|l|}{ Facial pain } \\
\hline Occurrence & $18(9.6 \%)$ & $18(12.0 \%)$ & $0(0.0 \%)$ \\
\hline Intensity & $0.20(0.64)$ & $0.25(0.71)$ & - \\
\hline \multicolumn{4}{|l|}{ Acoustic symptoms } \\
\hline Occurrence & $50(26.6 \%)$ & $50(33.3 \%)$ & $0(0.0 \%)$ \\
\hline \multicolumn{4}{|c|}{ Temporomandibular joint locking } \\
\hline Occurrence & $14(7.4 \%)$ & $14(9.3 \%)$ & $0(0.0 \%)$ \\
\hline \multicolumn{4}{|l|}{ Teeth clenching } \\
\hline Occurrence & $75(39.9 \%)$ & $75(50.0 \%)$ & $0(0.0 \%)$ \\
\hline \multicolumn{4}{|l|}{ Teeth grinding } \\
\hline Occurrence & $34(18.1 \%)$ & $34(22.7 \%)$ & $0(0.0 \%)$ \\
\hline \multicolumn{4}{|l|}{ Muscle tension } \\
\hline Occurrence & $45(23.9 \%)$ & $45(30.0 \%)$ & $0(0.0 \%)$ \\
\hline
\end{tabular}

* the number $(n)$ and percentage (\%) for the occurrence of symptoms ${ }^{* *}$ mean (M) and standard deviation (SD) for pain intensity.

As shown in Table 1, the most common symptoms of SS disorders reported by the participants included headaches $(68.0 \%)$, pain in the neck and shoulder girdle $(58.0 \%)$, teeth clenching (50.0\%) and acoustic symptoms in the temporomandibular joints (33.3\%).

\subsection{Statistical Analysis}

The results of the study were statistically analyzed using the IBM SPSS Statistics v. 25 package 9 (IBM, Armonk, NY, USA). To assess the compliance of the empirical distributions obtained in the study with the theoretical normal distribution, typical for general population, the Shapiro-Wilk test for small groups $(n<50)$ and the Kolmogorov-Smirnov test for large groups were implemented. The non-parametric Spearman correlation was used to analyze the relationships between the continuous variables, and the non-parametric Mann-Whitney $U$ test was used to assess the differences between the two independent groups. After standardizing the selected variables, the hierarchical regression model was also used, and the statistical significance index was established at $p<0.05$.

\section{Results}

Table 2 presents the effect of measuring the frequency of the intensity of stress in the studied groups. The participants scored the PSS-10 scale from low (four raw points, three sten) to very high (35 raw points, 10 sten), and the mean result in the group approaching 19 raw points was within the range of six sten, indicating average severity of stress. The median for the stress level in the P1 group was 20 points and this result was four points higher than in the P2 group-this difference was statistically significant $(Z=-2.665$; 
$p=0.008)$. Differences in sten scores were also significant $(Z=-2.768 ; p=0.006)$. The stress

level in the P1 group was higher than in the P2 group.

Table 2. Basic parameters of the distribution of stress measurement results in the study group $(n=188)$.

\begin{tabular}{ccccccccc}
\hline & PSS & Mean & SD & Median & Minimum & $\begin{array}{c}\text { Maximum } \\
\text { Normality of } \\
\text { Distribution }\end{array}$ \\
\hline \multirow{2}{*}{ Whole group } & Total score & 18.82 & 6.19 & 18.00 & 4.00 & 35.00 & 0.061 \\
\cline { 2 - 8 } & Sten score & 6.27 & 1.83 & 6.00 & 3.00 & 10.00 & $<0.001$ \\
\hline \multirow{2}{*}{ P1 } & Total score & 19.43 & 6.18 & 20.00 & 4.00 & 35.00 & 0.232 \\
\cline { 2 - 8 } & Sten score & 6.45 & 1.83 & 7.00 & 3.00 & 10.00 & 29.00 & 0.751 \\
\hline \multirow{2}{*}{ P2 } & Total score & 16.45 & 5.75 & 16.00 & 4.00 & 3.00 & 9.00 & 0.036 \\
\hline
\end{tabular}

Then, the correlation between the intensity of pain and stress in the P1 group $(n=150)$ was analyzed. The measurement data presented in Table 3 indicate that with the increase in the severity of the sense of stress, the severity of headache (rho $=0.359 ; p<0.001$ ) and pain in the neck and girdle (rho $=0.240 ; p=0.003$ ) increased as well.

Table 3. Analysis of the correlation between the intensity of stress and the intensity of pain in the P1 group.

\begin{tabular}{ccccc}
\hline PSS & TMD & Headache & Neck and Shoulder Girdle Pain & Facial Pain \\
\hline Raw score & 0.104 & $0.342^{* * *}$ & $0.241^{* *}$ & 0.139 \\
\hline Sten score & 0.090 & $0.359^{* * *}$ & $0.240^{* *}$ & 0.149 \\
\hline & $*^{* *} p<0.01 ; * * *<0.001$. &
\end{tabular}

Table 4 presents the results of measurements of two variables: stress intensity (according to PSS10) and type D personality (according to DS14) among participants who reported one symptom of SS disorders. The analyses were carried out separately for the group of females and males. Males and females differ in this respect; females experiencing at least one SS symptom were characterized by a significantly higher level of stress and a type D personality $(p<0.05)$ compared to P2 group. Among males, these differences were not statistically significant $(p>0.05)$.

Table 4. Comparison of the mean results of the measurement of stress and type D personality among people suffering from one SS symptom, taking into account gender.

\begin{tabular}{cccccc}
\hline \multirow{2}{*}{ Gender } & $\begin{array}{c}\text { Compared } \\
\text { Variables }\end{array}$ & \multicolumn{2}{c}{$\begin{array}{c}\text { Symptoms } \\
\text { Occurrence/Group }\end{array}$} & \multicolumn{2}{c}{ Group Comparison } \\
\cline { 2 - 6 } & & P1 & P2 & Z & $p$ \\
\hline \multirow{2}{*}{ Female } & PSS & $20.63(5.54)$ & $18.18(5.45)$ & -1.922 & 0.045 \\
\cline { 2 - 6 } & DS14 & $14.89(5.25)$ & $11.36(5.71)$ & -2.369 & 0.018 \\
\hline \multirow{2}{*}{ Male } & PSS & $16.79(6.73)$ & $12.53(6.61)$ & -1.266 & 0.206 \\
\cline { 2 - 6 } & DS14 & $14.06(5.42)$ & $8.75(4.31)$ & -1.878 & 0.060 \\
\hline
\end{tabular}

Table 5 summarizes the results of a hierarchical regression analysis explaining the intensity of stress experienced by the participants during the COVID-19 pandemic. In each of the five steps of the analysis, the model included successive groups of potential predictors of stress: coping strategies, occurrence of SS symptoms, pain intensity caused by these symptoms, type D personality index, and sociodemographic variables. Before the calculations were made, all data were standardized. It was assessed what percentage of the total variability (variance) in the observed stress intensity can be explained based 
on changes in individual potential predictors and which of the independent variables are statistically significant predictors. Ultimately, it was possible to explain more than half of the variability in the stress experienced by the participants during the pandemic.

Table 5. Hierarchical regression analysis explaining the intensity of stress among students during the pandemic.

\begin{tabular}{|c|c|c|c|c|c|c|c|c|c|c|}
\hline \multirow{2}{*}{ Significant Predictors } & \multicolumn{2}{|c|}{$\begin{array}{r}\text { Model 1, } \\
\mathrm{R}^{2}=0.328\end{array}$} & \multicolumn{2}{|c|}{$\begin{array}{c}\text { Model 2, } \\
\mathrm{R}^{2}=0.368\end{array}$} & \multicolumn{2}{|c|}{$\begin{array}{r}\text { Model 3, } \\
\mathrm{R}^{2}=0.375\end{array}$} & \multicolumn{2}{|c|}{$\begin{array}{c}\text { Model 4, } \\
\mathrm{R}^{2}=0.554\end{array}$} & \multicolumn{2}{|c|}{$\begin{array}{r}\text { Model 5, } \\
\mathrm{R}^{2}=0.579\end{array}$} \\
\hline & Beta & $p$ & Beta & $p$ & Beta & $p$ & Beta & $p$ & Beta & $p$ \\
\hline Positive evaluation & -0.17 & 0.034 & -0.20 & 0.014 & -0.22 & 0.007 & -0.06 & 0.422 & -0.06 & 0.349 \\
\hline Discharging & 0.27 & 0.004 & 0.23 & 0.002 & 0.24 & 0.001 & 0.12 & 0.027 & 0.13 & 0.043 \\
\hline Taking psychoactive substances & 0.13 & 0.041 & 0.12 & 0.047 & 0.11 & 0.094 & 0.13 & 0.027 & 0.15 & 0.007 \\
\hline Blaming oneself & 0.26 & $<0.001$ & 0.22 & 0.002 & 0.24 & 0.001 & 0.04 & 0.566 & 0.03 & 0.686 \\
\hline Headache & - & - & 0.20 & 0.006 & 0.05 & 0.700 & 0.07 & 0.522 & 0.05 & 0.660 \\
\hline Intensified Neck pain & - & - & - & - & -0.31 & 0.022 & -0.20 & 0.085 & -0.23 & 0.040 \\
\hline DS14 & - & - & - & - & - & - & 0.56 & $<0.001$ & 0.53 & $<0.001$ \\
\hline Gender & - & - & - & - & - & - & - & - & -0.20 & 0.001 \\
\hline
\end{tabular}

(1) In the first step, the possibility to predict the level of stress severity during the pandemic by applying the strategies of coping with stress among the participants was assessed. Out of 14 strategies, four were significant predictors, which accounted for $33 \%$ of the stress variance.

The analysis showed that the higher the level of positive evaluation, the lower the level of stress. The other three strategies: discharging, taking psychoactive substances, and blaming oneself were positively related to the stress level.

(2) In the second step, after adding the presence of SS symptoms alone to the model, the explained variance increased to almost $37 \%$, which was a statistically significant change $(\mathrm{X} 2(10.163)=2.087 ; p=0.002)$. The occurrence of headaches alone became a significant predictor of stress and caused its intensification. All remedial strategies detected in Model 1 as significant maintained their statistical significance $(p<0.05)$.

(3) In the third model, the intensity of the symptoms of the SS was added as a pool of potential predictors. Including them in the model did not significantly increase the percentage of the explained stress variance $(\mathrm{X} 2(4.159)=1.468 ; p=0.214 ;$ up to $38 \%$ of variance). The severity of pain in the neck and shoulder girdle was a significant predictoran increase in pain intensity in this area coexisted with a decrease in stress intensity. At the same time, after taking this predictor into account, the strategy of taking psychoactive substances and the occurrence of headaches became statistically insignificant.

(4) The fourth model included the results of measuring type D personality as a potential stress predictor, which resulted in a significant increase in the explained variance to $55 \%(X 2(1.158)=64.591 ; p<0.001)$. Of the temporary remedial strategies, only discharging and taking psychoactive substances remained relevant, and both previously diagnosed symptoms of SS lost their relevance. The result on the DS14 scale was the strongest predictor of stress, positively related to the explained variable. The increase in DS14 caused an increase in the level of stress.

(5) In the fifth model, additionally, a sociodemographic variable was introduced. The gender variable resulted in a significant increase in the explained variance of the stress intensity among students during the pandemic to $58 \%(X 2(3.155)=4.109 ; p=0.008)$. Among the implemented remedial strategies, the statistical significance was maintained by the discharging and taking psychoactive substances, and among the symptoms of SS, the increase in pain in the neck and shoulder girdle. The sum of type $D$ personality indices was still the strongest predictor, while in the sociodemographic variable-gender-women were characterized by a greater intensity of stress than men.

Table 6 presents the results of the analysis of the correlation between the severity of stress and the styles of coping with it and DS14. It has been shown that the increase in type $\mathrm{D}$ personality manifestations was positively and moderately strongly associated 
with the overall intensity of stress (rho $=0.69 ; p<0.001)$; participants with higher levels of stress were characterized by a greater number of type $\mathrm{D}$ personality symptoms. Moreover, this personality type was correlated with seven strategies for coping with stress. The severity of symptoms increased moderately with the increase in the tendency to blame oneself in problem situations ( $\mathrm{rho}=0.51 ; p<0.001$ ), and it also increased slightly with the increase in the tendency to denial ( $\mathrm{rho}=0.31 ; p<0.001)$, discharging (rho $=0.27 ; p<0.001$ ), taking psychoactive substances ( $\mathrm{rho}=0.19 ; p=0.009$ ) and engaging in other activities $(\mathrm{rho}=0.17 ; p=0.019)$ and with a decrease in such constructive remedial strategies as positive reevaluation (rho $=-0.29 ; p<0.001$ ) and sense of humor ( $\mathrm{rho}=-0.19 ; p=0.0010$ ). The overall severity of stress moderately increased with the increase in tendency to blame oneself (rho $=0.46 ; p<0.001)$ and weakly with the increase in ceasing activities (rho $=0.32$; $p<0.001)$, discharging (rho $=0.31 ; p<0.001)$, taking psychoactive substances ( $\mathrm{rho}=0.27$; $p<0.001)$, denial (rho $=0.20 ; p=0.007)$, engaging in other activities (rho $=0.15 ; p=0.042)$, and with a decrease in the tendency to positively re-evaluate (rho $=-0.27 ; p<0.001$ ), sense of humor (rho $=-0.21 ; p=0.004)$, active coping ( $\mathrm{rho}=-0.17 ; p=0.018)$, planning $(\mathrm{rho}=-0.16 ; p=0.028)$, or seeking emotional support $(\mathrm{rho}=-0.14 ; p=0.047)$. 
Table 6. Spearman's correlation matrix.

\begin{tabular}{|c|c|c|c|c|c|c|c|c|c|c|c|c|c|c|c|}
\hline Variables & 1 & 2 & 3 & 4 & 5 & 6 & 7 & 8 & 9 & 10 & 11 & 12 & 13 & 14 & 15 \\
\hline 1. DS14 & - & - & - & - & - & - & - & - & - & - & - & - & - & - & - \\
\hline 2. PSS 10 & $0.69^{* * *}$ & - & - & - & - & - & - & - & - & - & - & - & - & - & - \\
\hline 3. Active coping & -0.14 & $-0.17^{*}$ & - & - & - & - & - & - & - & - & - & - & - & - & - \\
\hline $\begin{array}{l}5 \text {. Positive } \\
\text { evaluation }\end{array}$ & $-0.29^{* * *}$ & $-0.27^{* * *}$ & $0.19^{*}$ & $0.40^{* * *}$ & - & - & - & - & - & - & - & - & - & - & - \\
\hline 6. Acceptance & -0.03 & -0.13 & $0.21^{* *}$ & $0.29^{* * *}$ & $0.35^{* * *}$ & - & - & - & - & - & - & - & - & - & - \\
\hline $\begin{array}{l}\text { 7. Sense of } \\
\text { humor }\end{array}$ & $-0.19 *$ & $-0.21^{* *}$ & 0.01 & 0.02 & $0.39 * * *$ & $0.40^{* * *}$ & - & - & - & - & - & - & - & - & - \\
\hline $\begin{array}{l}\text { 8. Turning to } \\
\text { religion }\end{array}$ & -0.03 & -0.02 & 0.07 & $0.15^{*}$ & $0.18^{*}$ & 0.12 & 0.07 & - & - & - & - & - & - & - & - \\
\hline $\begin{array}{l}\text { 9. Seeking } \\
\text { emotional } \\
\text { support }\end{array}$ & -0.12 & $-0.14 *$ & $0.20^{* *}$ & $0.34^{* * *}$ & $0.35 * * *$ & $0.16^{*}$ & -0.02 & 0.11 & - & - & - & - & - & - & - \\
\hline $\begin{array}{c}\text { 10. Seeking } \\
\text { instrumental } \\
\text { support }\end{array}$ & -0.04 & -0.04 & $0.18^{*}$ & $0.27^{* * *}$ & $0.34^{* * *}$ & $0.19 *$ & -0.03 & $0.21^{* *}$ & $0.77^{* * *}$ & - & - & - & - & - & - \\
\hline $\begin{array}{l}\text { 11. Engaging in } \\
\text { other activities }\end{array}$ & $0.17^{*}$ & $0.15^{*}$ & -0.01 & 0.11 & 0.11 & $0.15^{*}$ & $0.15^{*}$ & 0.03 & $0.16^{*}$ & $0.17^{*}$ & - & - & - & - & - \\
\hline 12. Denial & $0.14^{*}$ & $0.20 * *$ & -0.06 & -0.06 & 0.05 & -0.05 & 0.12 & 0.09 & $-0.17^{*}$ & -0.11 & 0.12 & - & - & - & - \\
\hline $\begin{array}{l}\text { 14. Taking } \\
\text { psychoactive } \\
\text { substance }\end{array}$ & $0.19 * *$ & $0.27^{* * *}$ & -0.07 & -0.02 & -0.08 & 0.03 & 0.12 & 0.03 & -0.12 & -0.12 & $0.19^{* *}$ & 0.14 & 0.12 & - & - \\
\hline $\begin{array}{c}\text { 15. Ceasing } \\
\text { activities }\end{array}$ & $0.31^{* * *}$ & $0.32^{* * *}$ & $-0.45^{* * *}$ & $-0.29 * * *$ & $-0.19^{* *}$ & -0.01 & -0.01 & -0.03 & $-0.24 * *$ & -0.09 & -0.06 & $0.27^{* * *}$ & $0.21^{* *}$ & 0.13 & - \\
\hline $\begin{array}{l}\text { 16. Blaming } \\
\text { oneself }\end{array}$ & $0.51 * * *$ & $0.46^{* * *}$ & 0.01 & -0.09 & $-0.19^{* *}$ & -0.10 & $-0.16^{*}$ & 0.05 & $0.14^{*}$ & 0.01 & 0.06 & $0.28^{* * *}$ & $0.25^{* * *}$ & $0.27^{* * *}$ & $0.26^{* * *}$ \\
\hline
\end{tabular}




\section{Discussion}

The outbreak of the COVID-19 pandemic generated a global public health emergency [55-58]. Taylor et al. reported that psychological responses to previous epidemics and pandemics depended on individual vulnerabilities such as intolerance, insecurity, disease susceptibility, and anxiety [59]. Therefore, the authors of the present study conducted research on the assessment of the level of stress, the method of coping with stress, and the occurrence of symptoms of SS disorders in students of physiotherapy during the COVID-19 pandemic.

Multiple researchers emphasized the importance of mental stress in shaping the pathology of the SS [17-20]. Stressors with somatic consequences are largely dependent on the patient's personality type and the ability to cope with stress. The long-term effects of stressors breaks the body's adaptive mechanisms and lead to the accumulation of various disorders, including SS disorders [60]. According to the authors' research on a group of 188 physiotherapy students, the symptoms of SS disorders were found in 150 participants (80\%). Research conducted by Emodi-Perlaman et al. showed that the COVID-19 pandemic had a significant adverse effect on the psychoemotional state of Israeli and Polish populations, leading to an increase in bruxism and TMD symptoms [61]. In the author's own research, symptoms of bruxism, i.e., tooth clenching, were found in 75 participants and teeth grinding in 34 (50\% and $22.7 \%$, respectively). In studies by Przytańska et al., patients with high levels of stress reported parafunctional functions, i.e., awake bruxism, almost six times more often [62].

As it results from the conducted research, in the group of students with symptoms of SS disorders, higher scores were observed in the stress severity rating scale compared to the group without SS symptoms. The difference between the groups was statistically significant, which may indicate a significant role of stress in the development of SS disorders. De Medeiros et al. conducted research among Brazilian medical students and indicated that social isolation and stressful situations caused by the pandemic may increase the number of people with TMD symptoms [63].

It is generally accepted that mental stress causes increase in the muscular tension in different parts of the body $[64,65]$. The body posture adopted in stressful situations related to the so-called "fight or flight" reaction affects muscle contractions within the SS, leading to pain in the head and neck area. Therefore, muscle contractions in the body's upper quadrant may be a part of a stress-related defensive behavior [14-17]. In our study, the majority of physiotherapy students reported at least one symptom of SS and pain. The most common symptoms were headache (68\%), neck and shoulder pain $(58 \%)$, and teeth clenching (50\%). Many clinical studies seem to confirm the relationship between the occurrence of SS disorders and severe stress, mostly in young people entering adulthood [66-69]. According to Quintiliani et al., as many as $89.4 \%$ of the respondents experienced an increase in perceived stress during the pandemic $(66 \%$ reported moderate stress and $23.4 \%$ high stress) [70].

The authors of the study, by using the PSS 10 scale, found that the average stress intensity among physiotherapy students was in the range of six sten (19 raw points), indicating the average intensity of stress. Similar conclusions were drawn by other authors assessing the intensity of stress in emergency medical students, who also obtained an average value of six [70]. Importantly, in the present study, as many as $46.3 \%$ of the respondents obtained results in the range of 7-10 sten, which, according to the current interpretation of the research tool (PSS 10), qualifies them as high stress subjects. It is also worth noting that the maximum score on the PSS 10 scale in the group with symptoms of SSD was higher than in the control group.

The relationship between stress and neurological disorders, and tension headaches and migraines has been expensively described [71-74]. The results of our own research confirmed the existence of positive correlations between the intensity of stress and the symptoms of SS disorders, because with the increase in the intensity of the sense of stress, the intensity of headache and pain in the neck and shoulder girdle also increased. The 
above fact should prompt clinicians to evaluate the structures of SS in patients who report the above-mentioned pain symptoms in their history.

According to the literature, SS disorders and higher levels of stress are more common in women than in men [75-78]. Wang et al. found three times higher levels of depression and health anxiety in women than in men during the COVID-19 pandemic [79]. Moreover, in the research by Liu et al., women were stronger predictors of PTSS symptoms after the pandemic [80]. Our results are in accordance with the abovementioned findings, as we discovered that women with a symptom of SS disorders were characterized by a significantly higher level of stress and a type D personality $(p<0.005)$ compared to men $(p>0.05)$.

The analyses carried out by the authors of the publication with the use of the MiniCOPE test were aimed at examining the activity that students undertake in a stressful situation. These actions are known as "coping methods". Research conducted by BabickaWirkus et al. on a group of 577 students from 17 Polish universities showed that, during the COVID-19 pandemic, students most often used coping strategies such as acceptance, planning, and seeking emotional support [81]. The analysis of the authors' results did not bring similar conclusions, because out of 14 strategies, four were significant predictors, i.e., positive thinking strategies, discharge, taking psychoactive substances, and blaming oneself. The results also showed that the higher the level of perceived stress, the more frequently the remaining three strategies were used. The level of perceived stress most strongly influenced the frequency of using the discharge strategy, which is a strategy focusing on revealing negative emotions and is associated with a feeling of mental discomfort. The results obtained by the authors allow for the conclusion that maladaptive stress coping strategies in students, especially during the pandemic, may have long-term consequences for their psychophysiological health and academic achievement. According to the research, the presence of SS symptoms did not contribute to changes in the way of coping as all coping strategies retained their statistical significance $(p<0.05)$.

As it was shown in the study, the intensity of type D personality manifestations was positively and moderately strongly associated with the general intensity of stress $($ rho $=0.690 ; p<0.001)$. Students experiencing higher levels of stress exhibited more symptoms of type D personality, and those with more severe symptoms showed higher levels of stress. In a study by Cho et al. conducted among Korean students, it was observed that type D personality is related to the level of perceived stress. Additionally, it has been concluded that there are gender differences in type D personality, stress, and coping strategies [82].

By analyzing the available scientific literature and the results of our own research, it can be determined with high probability that the COVID-19 pandemic increases the intensity of stress and may influence the development of SS disorders.

More research is required to better understand the impact of COVID-19 stressors on stomatognathic disorders.

The major limitation of the present study is the fact that it was carried out in a very specific population. Therefore, the results cannot be extrapolated convincingly to the general population.

\section{Conclusions}

1. The degree of stress intensity influences the occurrence symptoms of the stomatognathic system such as: headache, neck, and shoulder girdle pain.

2. It is important to develop and implement psychological support measures to deal with the COVID-19 pandemic for medical college students.

3. Dental care workers are encouraged to pay more attention to the occurrence of symptoms of SSDs in patients during the pandemic. 
Author Contributions: Conceptualization: M.G., Ł.K.; Methodology: M.G., B.D.; Software: M.G., Ł.K.; Validation: M.G.; Formal analysis: M.G.; Investigation: M.G., Ł.K.; Resources: Ł.K.; Data curation: M.G., Ł.K.; Writing—original draft preparation: M.G., B.D., Ł.P.; Writing—review and editing: B.D., Ł.P., M.G.; Visualization: M.G.; Supervision: E.S., Ł.P.; Project administration: M.G.; Funding acquisition: E.S. All authors have read and agreed to the published version of the manuscript.

Funding: This research received no external funding.

Institutional Review Board Statement: Not applicable.

Informed Consent Statement: Informed consent was obtained from all subjects involved in the study.

Data Availability Statement: The data presented in this study are available on request from the corresponding author. The data are not publicly available due to sensitive information.

Conflicts of Interest: The authors declare no conflict of interest.

\section{References}

1. Hu, Z.; Lin, X.; Kaminga, A.C.; Xu, H. Impact of the COVID-19 Epidemic on Lifestyle Behaviors and Their Association With Subjective Well-Being Among the General Population in Mainland China: Cross-Sectional Study. J. Med. Internet Res. 2020, 22, e21176. [CrossRef]

2. Maqsood, A.; Abbas, J.; Rehman, G.; Mubeen, R. The paradigm shift for educational system continuance in the advent of COVID-19 pandemic: Mental health challenges and reflections. Curr. Res. Behav. Sci. 2021, 2, 100011. [CrossRef]

3. Brooks, S.K.; Webster, R.K.; Smith, L.E.; Woodland, L.; Wessely, S.; Greenberg, N.; Rubin, G.J. The psychological impact of quarantine and how to reduce it: Rapid review of the evidence. Lancet 2020, 395, 912-920. [CrossRef]

4. Dalewski, B.; Palka, L.; Kiczmer, P.; Sobolewska, E. The Impact of SARS-CoV-2 Outbreak on the Polish Dental Community's Standards of Care-A Six-Month Retrospective Survey-Based Study. Int. J. Environ. Res. Public Health 2021, $18,1281$. [CrossRef] [PubMed]

5. $\quad$ Fillingim, R.; Slade, G.D.; Greenspan, J.D.; Dubner, R.; Maixner, W.; Bair, E.; Ohrbach, R. Long-term changes in biopsychosocial characteristics related to temporomandibular disorder: Findings from the OPPERA study. Pain 2018, 159, 2403-2413. [CrossRef]

6. Neylan, T.C. Hans Selye and the Field of Stress Research. J. Neuropsychiatry Clin. Neurosci. 1998, 10, 230. [CrossRef]

7. Nagata, K.; Hori, S.; Mizuhashi, R.; Yokoe, T.; Atsumi, Y.; Nagai, W.; Goto, M. Efficacy of mandibular manipulation technique for temporomandibular disorders patients with mouth opening limitation: A randomized controlled trial for comparison with improved multimodal therapy. J. Prosthodont. Res. 2018, 63, 202-209. [CrossRef] [PubMed]

8. Kapos, F.P.; Look, J.O.; Zhang, L.; Hodges, J.S.; Schiffman, E.L. Predictors of Long-Term Temporomandibular Disorder Pain Intensity: An 8-Year Cohort Study. J. Oral Facial Pain Headache 2018, 32, 113-122. [CrossRef]

9. Polat, M.; Yanik, S. Efficiency of arthrocentesis treatment for different temporomandibular joint disorders. Int. J. Oral Maxillofac. Surg. 2020, 49, 621-627. [CrossRef]

10. Vrbanović, E.; Alajbeg, I.Z. Long-term Effectiveness of Occlusal Splint Therapy Compared to Placebo in Patients with Chronic Temporomandibular Disorders. Acta Stomatol. Croat. 2019, 53, 195-206. [CrossRef]

11. Guo, Y.-N.; Cui, S.-J.; Zhou, Y.-H.; Wang, X.-D. An Overview of Anterior Repositioning Splint Therapy for Disc Displacementrelated Temporomandibular Disorders. Curr. Med. Sci. 2021, 41, 1-9. [CrossRef]

12. Nascimento, G.C.; De Paula, B.B.; Gerlach, R.F.; Leite-Panissi, C.R.A. Temporomandibular inflammation regulates the matrix metalloproteinases MMP-2 and MMP-9 in limbic structures. J. Cell. Physiol. 2021, 236, 6571-6580. [CrossRef]

13. Zhang, H.-Y.; Duan, J.; Wang, J.; Xie, M.-J.; Liu, Q.; Liu, J.-Q.; Yang, H.-X.; Wang, M.-Q. Masseter response to long-term experimentally induced anterior crossbite in Sprague-Dawley rats. Arch. Oral Biol. 2021, 122, 104985. [CrossRef]

14. Ploder, O.; Sigron, G.; Adekunle, A.; Burger-Krebes, L.; Haller, B.; Kolk, A. The Effect of Orthognathic Surgery on Temporomandibular Joint Function and Symptoms: What are the Risk Factors? A Longitudinal Analysis of 375 Patients. J. Oral Maxillofac. Surg. 2020, 79, 763-773. [CrossRef]

15. Fisch, G.; Finke, A.; Ragonese, J.; Dugas, L.; Wrzosek, M. Outcomes of physical therapy in patients with temporomandibular disorder: A retrospective review. Br. J. Oral Maxillofac. Surg. 2021, 59, 145-150. [CrossRef]

16. Kolk, A.; Scheunemann, L.-M.; Grill, F.; Stimmer, H.; Wolff, K.-D.; Neff, A. Prognostic factors for long-term results after condylar head fractures: A comparative study of non-surgical treatment versus open reduction and osteosynthesis. J. Cranio-Maxillofac. Surg. 2020, 48, 1138-1145. [CrossRef]

17. Braga, S.P.; Fiamengui, L.M.S.P.; Da Silveira, V.R.S.; Chaves, H.V.; Furquim, B.D.; Cunha, C.O.; Repeke, C.E.P.; Conti, P.C.R. Insights for temporomandibular disorders management: From psychosocial factors to genetics-A case report. Spéc. Care Dent. 2021, 41, 85-91. [CrossRef] [PubMed]

18. Seo, H.; Jung, B.; Yeo, J.; Kim, K.-W.; Cho, J.-H.; Lee, Y.J.; Ha, I.-H. Healthcare utilisation and costs for temporomandibular disorders: A descriptive, cross-sectional study. BMJ Open 2020, 10, e036768. [CrossRef] [PubMed]

19. Bergmann, A.; Edelhoff, D.; Schubert, O.; Erdelt, K.-J.; Duc, J.-M.P. Effect of treatment with a full-occlusion biofeedback splint on sleep bruxism and TMD pain: A randomized controlled clinical trial. Clin. Oral Investig. 2020, 24, 4005-4018. [CrossRef] [PubMed] 
20. Wahlund, K.; Larsson, B. The course of pain intensity and frequency of adolescents treated because of temporomandibular disorders: A long-term follow-up. Clin. Exp. Dent. Res. 2020, 6, 407-414. [CrossRef] [PubMed]

21. Dalewski, B.; Kamińska, A.; Białkowska, K.; Jakubowska, A.; Sobolewska, E. Association of Estrogen Receptor 1 and Tumor Necrosis Factor $\alpha$ Polymorphisms with Temporomandibular Joint Anterior Disc Displacement without Reduction. Dis. Markers 2020, 2020, 6351817. [CrossRef] [PubMed]

22. Dalewski, B.; Kaczmarek, K.; Jakubowska, A.; Szczuchniak, K.; Pałka, Ł.; Sobolewska, E. COL12A1 Single Nucleotide Polymorphisms rs240736 and rs970547 Are Not Associated with Temporomandibular Joint Disc Displacement without Reduction. Genes 2021, 12, 690. [CrossRef] [PubMed]

23. Checherita, L.E.; Stamatin, O.; Liana, A.; Luca, D.E. Parafunctions in dysfunctional syndrome of the stomatognathic system-literature review. Rom. J. Med. Dent. Educ. 2020, 9, 53-61.

24. Dalewski, B.; Kamińska, A.; Kiczmer, P.; Wegrzyn, K.; Pałka, Ł.; Janda, K.; Sobolewska, E. Pressure Algometry Evaluation of Two Occlusal Splint Designs in Bruxism Management-Randomized, Controlled Clinical Trial. J. Clin. Med. 2021, 10, 2342. [CrossRef] [PubMed]

25. Leketas, M. Stomatognathic Parafunctions and Their Etiology: Literature Review. Master's Thesis, Lithuanian University of Health Sciences Medical Academy Faculty of Medicine, Department of Oral and Maxillofacial Surgery, Kanuas, Lithuania, 2018.

26. Wolowski, A.; Eger, T.; Braas, R.; Gohr, J.; Weber, N.; Witanski, K.; Wörner, F. Long-term effects of splint therapy in patients with posttraumatic stress disease (PTSD). Clin. Oral Investig. 2020, 24, 1493-1497. [CrossRef] [PubMed]

27. Xin, Y.; Wu, J.; Yao, Z.; Guan, Q.; Aleman, A.; Luo, Y. The relationship between personality and the response to acute psychological stress. Sci Rep. 2017, 7, 16906. [CrossRef] [PubMed]

28. Bacon, S.L.; Moullec, G. Type-D Personality and Heart Disease: It Might Be 'One Small Step', but It Is Still Moving Forward: A Comment on Grande et al. Ann. Behav. Med. 2012, 43, 280-281. [CrossRef]

29. O'Riordan, A.; Howard, S.; Gallagher, S. Type D personality and life event stress: The mediating effects of social support and negative social relationships. Anxiety Stress. Coping 2020, 33, 452-465. [CrossRef]

30. Mols, F.; Denollet, J. Type D personality in the general population: A systematic review of health status, mechanisms of disease, and work-related problems. Health Qual. Life Outcomes 2010, 8, 9. [CrossRef]

31. Raykh, O.I.; Sumin, A.N.; Kokov, A.N.; Indukaeva, E.V.; Artamonova, G.V. Association of type D personality and level of coronary artery calcification. J. Psychosom. Res. 2020, 139, 110265. [CrossRef]

32. Chilicka, K.; Rogowska, A.M.; Szyguła, R.; Adamczyk, E. Association between Satisfaction with Life and Personality Types A and D in Young Women with Acne Vulgaris. Int. J. Environ. Res. Public Health 2020, 17, 8524. [CrossRef] [PubMed]

33. Raykh, O.I.; Sumin, A.N.; Korok, E.V. The Influence of Personality Type D on Cardiovascular Prognosis in Patients After Coronary Artery Bypass Grafting: Data from a 5-Year-Follow-up Study. Int. J. Behav. Med. 2021, 6, 1-11. [CrossRef]

34. Jordi, S.B.U.; Botte, F.; Lang, B.M.; Greuter, T.; Krupka, N.; Auschra, B.; Schreiner, P.; Sulz, M.C.; Biedermann, L.; von Känel, R.; et al. Type D personality is associated with depressive symptoms and clinical activity in inflammatory bowel disease. Aliment. Pharmacol. Ther. 2021, 54, 53-67. [CrossRef] [PubMed]

35. Zhan, H.; Zheng, C.; Zhang, X.; Yang, M.; Zhang, L.; Jia, X. Chinese College Students' Stress and Anxiety Levels Under COVID-19. Front. Psychiatry 2021, 12, 615390. [CrossRef] [PubMed]

36. Kim, E.-J.; Nho, J.-H.; Kim, H.-Y.; Park, S.-K. The Effects of Lifestyle Interventions on the Health-Promoting Behavior, Type D Personality, Cognitive Function and Body Composition of Low-Income Middle-Aged Korean Women. Int. J. Environ. Res. Public Health 2021, 18, 5637. [CrossRef] [PubMed]

37. O'Riordan, A.; Howard, S.; Brown, E.; Gallagher, S. Type D personality and cardiovascular reactivity to acute stress: The mediating effects of social support and negative social relationships. Psychophysiology 2020, 57, 13660. [CrossRef] [PubMed]

38. Köbling, T.; Váradi, Z.; Katona, É.; Somodi, S.; Kempler, P.; Páll, D.; Zrínyi, M. Predictors of dietary self-efficacy in high glycosylated hemoglobin A1c type 2 diabetic patients. J. Int. Med. Res. 2020, 48, 300060520931284. [CrossRef]

39. Kołtuniuk, A.; Kazimierska-Zając, M.; Cisek, K.; Chojdak-Łukasiewicz, J. The Role of Stress Perception and Coping with Stress and the Quality of Life Among Multiple Sclerosis Patients. Psychol. Res. Behav. Manag. 2021, 14, 805-815. [CrossRef]

40. Ali, H.; Ismail, A.A.; Abdalwahab, A. Mental Stress in Anesthesia and Intensive Care Physicians During COVID-19 Outbreak. Anesthesiol. Pain Med. 2020, 10, 106623. [CrossRef]

41. Avunduk, A.T.E.; Delikan, E. Satisfaction and stress levels of dentistry students relating to distance education. Dent. Med. Probl. 2021, 58, 58. [CrossRef]

42. Grabowski, J.; Stepien, J.; Waszak, P.; Michalski, T.; Meloni, R.; Grabkowska, M.; Macul, A.; Rojek, J.; Lorettu, L.; Sagan, I.; et al. Social Isolation During COVID-19 Pandemic. Perceived Stress and Containment Measures Compliance Among Polish and Italian Residents. Front. Psychol. 2021, 12, 673514. [CrossRef] [PubMed]

43. Ziarko, M.; Jasielska, A.; Stanisławska-Kubiak, M.; Daroszewski, P.; Samborski, W.; Mojs, E. Mental Health Outcomes Associated with COVID-19 Pandemic in a Group of Health Care Professionals. J. Behav. Health Serv. Res. 2021, 1-10. [CrossRef]

44. Kowalczuk, K.; Krajewska-Kułak, E.; Sobolewski, M. Relationships Between Sleep Problems and Stress Coping Strategies Adopted by Nurses Including Socio-Occupational Factors. Front. Psychiatry 2021, 12, 660776. [CrossRef] [PubMed]

45. Betke, K.; Basińska, M.A.; Andruszkiewicz, A. Sense of coherence and strategies for coping with stress among nurses. BMC Nurs. 2021, 20, 1-10. [CrossRef] 
46. Chodkiewicz, J.; Miniszewska, J.; Krajewska, E.; Biliński, P. Mental Health during the Second Wave of the COVID-19 PandemicPolish Studies. Int. J. Environ. Res. Public Health 2021, 18, 3423. [CrossRef] [PubMed]

47. Mocny-Pachońska, K.; Trzcionka, A.; Doniec, R.; Sieciński, S.; Tanasiewicz, M. The Influence of Gender and Year of Study on Stress Levels and Coping Strategies among Polish Dental. Medicine 2020, 56, 531. [CrossRef] [PubMed]

48. Unnithan, A.S.; Chidgey, B.A. Pre-visit education on pain management options prior to the first clinic visit improves chronic pain patient satisfaction with proposed treatment plans. Pain Med. 2021. [CrossRef]

49. Dasukil, S.; Arora, G.; Shetty, S.K.; Degala, S. Impact of prolotherapy in temporomandibular joint disorder: A quality of life assessment. Br. J. Oral Maxillofac. Surg. 2020, 59, 599. [CrossRef] [PubMed]

50. Lindfors, E.; Arima, T.; Baad-Hansen, L.; Bakke, M.; De Laat, A.; Giannakopoulos, N.N.; Glaros, A.; Guimarães, A.S.; Johansson, A.; Le Bell, Y.; et al. Jaw Exercises in the Treatment of Temporomandibular Disorders-An International Modified Delphi Study. J. Oral Facial Pain Headache 2019, 39, 389-398. [CrossRef] [PubMed]

51. Lindfors, E.; Magnusson, T.; Ernberg, M. Patients' experiences of therapeutic jaw exercises in the treatment of masticatory myofascial pain-A postal questionnaire study. J. Oral Rehabil. 2019, 46, 800-806. [CrossRef]

52. Muzalev, K.; Van Selms, M.K.; Lobbezoo, F. No Dose-Response Association Between Self-Reported Bruxism and Pain-Related Temporomandibular Disorders: A Retrospective Study. J. Oral Facial Pain Headache 2018, 32, 375-380. [CrossRef]

53. Simma, I.; Simma, L.; Fleckenstein, J. Muscular Diagnostics and the Feasibility of Microsystem Acupuncture as a Potential Adjunct in the Treatment of Painful Temporomandibular Disorders: Results of a Retrospective Cohort Study. Acupunct. Med. 2018, 36, 415-421. [CrossRef] [PubMed]

54. Asquini, G.; Rushton, A.; Pitance, L.; Heneghan, N.; Falla, D. The effectiveness of manual therapy applied to craniomandibular structures in the treatment of temporomandibular disorders: Protocol for a systematic review. Syst. Rev. 2021, 10, 1-7. [CrossRef] [PubMed]

55. Peng, X.; Zhao, H.-Z.; Yang, Y.; Rao, Z.-L.; Hu, D.-Y.; He, Q. Post-traumatic Growth Level and Its Influencing Factors Among Frontline Nurses During the COVID-19 Pandemic. Front. Psychiatry 2021, 12, 632360. [CrossRef] [PubMed]

56. Yamaguchi, T. Neural circuit mechanisms of sex and fighting in males. Neurosci. Res. 2021, 0168. [CrossRef]

57. Krupa, S.; Paweł, W.; Mędrzycka-Dąbrowska, W.; Lintowska, A.; Ozga, D. Sleep Disturbances in Individuals Quarantined Due to SARS-CoV-2 Pandemic in Poland: A Mixed Methods Design Study. Glob. Adv. Health Med. 2021, 10. [CrossRef] [PubMed]

58. Volkan, E. COVID-19: Structural Considerations for Virus Pathogenesis, Therapeutic Strategies and Vaccine Design in the Novel SARS-CoV-2 Variants Era. Mol. Biotechnol. 2021, 1-13. [CrossRef]

59. Taylor, S. The Psychology of Pandemics: Preparing for the Next Global Outbreak of Infectious Disease; Cambridge Scholars Publishing: Cambridge, UK, 2019.

60. Dołoszycka, M.; Kulesa-Mrowiecka, M.; Kopański, Z.; Krzemiński, D.; Ptak, W.; Dyl, S.; Sklyarov, I. Behaviors leading to the occurrence of stomatognathic system disorders among students. J. Publ. Health Nurs. Med. Rescue. 2018, 6, 35-41.

61. Emodi-Perlman, A.; Eli, I.; Smardz, J.; Uziel, N.; Wieckiewicz, G.; Gilon, E.; Grychowska, N.; Wieckiewicz, M. Temporomandibular Disorders and Bruxism Outbreak as a Possible Factor of Orofacial Pain Worsening during the COVID-19 Pandemic-Concomitant Research in Two Countries. J. Clin. Med. 2020, 9, 3250. [CrossRef]

62. Przystańska, A.; Jasielska, A.; Ziarko, M.; Pobudek-Radzikowska, M.; Maciejewska-Szaniec, Z.; Prylińska-Czyżewska, A.; Czajka-Jakubowska, A. Psychosocialpredictors of bruxism. BioMed Res. Int. 2019, 2019, 2069716. [CrossRef]

63. Medeiros, R.A.D.; Vieira, D.L.; Silva, E.V.F.D.; Rezende, L.V.M.D.L.; Santos, R.W.D.; Tabata, L.F. Prevalence of symptoms of temporomandibular disorders, oral behaviors, anxiety, and depression in Dentistry students during the period of social isolation due to COVID-19. J. Appl. Oral Sci. 2020, 28, e20200445. [CrossRef]

64. Tassani, S.; Font-Llagunes, J.M.; Ballester, M.; Ángel, G.; Noailly, J. Muscular tension significantly affects stability in standing posture. Gait Posture 2019, 68, 220-226. [CrossRef] [PubMed]

65. Ekman, A.; Hagberg, M.; Wahlström, J.; Lindegård, A.; Ahlborg, G., Jr. Perceived muscular tension, emotional stress, psychological demands and physical load during VDU work. Int. Arch. Occup. Environ. Health 2003, 76, 584-590. [CrossRef]

66. Reissmann, D.R.; John, M.T.; Schierz, O.; Seedorf, H.; Doering, S. Stress-related adaptive versus maladaptive coping and temporomandibular disorder pain. J. Orofac. Pain 2012, 26, 181.

67. Schmitter, M.; Kares-Vrincianu, A.; Kares, H.; Bermejo, J.L.; Schindler, H.-J. Sleep-associated aspects of myofascial pain in the orofacial area among Temporomandibular Disorder patients and controls. Sleep Med. 2015, 16, 1056-1061. [CrossRef]

68. Staniszewski, K.; Lygre, H.; Bifulco, E.; Kvinnsland, S.; Willassen, L.; Helgeland, E.; Berge, T.; Rosén, A. Temporomandibular Disorders Related to Stress and HPA-Axis Regulation. Pain Res. Manag. 2018, 2018, 1-7. [CrossRef] [PubMed]

69. Augusto, V.G.; Perina, K.C.B.; Penha, D.S.G.; Dos Santos, D.C.A.; Oliveira, V.A.S. Temporomandibular Dysfunction, Stress and Common Mental Disorder in University Students. Acta Ortopédica Bras. 2016, 24, 330-333. [CrossRef]

70. Quintiliani, L.; Sisto, A.; Vicinanza, F.; Curcio, G.; Tambone, V. Resilience and psychological impact on Italian university students during COVID-19 pandemic. Distance learning and health. Psychol. Health Med. 2021, 12, 1-12. [CrossRef] [PubMed]

71. Bartczak, M.; Bartczak, M. Stress intensity and ways of coping with stress in paramedics and emergency medical students. Sci. Yearb. Univ. Kujawsko-Pomor. 2010, 5, 7-17.

72. Cathcart, S.; Winefield, A.H.; Lushington, K.; Rolan, P. Stress and tension-type headache mechanisms. Cephalalgia 2010, 30, 1250-1267. [CrossRef] 
73. Maleki, N.; Becerra, L.; Borsook, D. Migraine: Maladaptive Brain Responses to Stress. Headache J. Head Face Pain 2012, 52, $102-106$. [CrossRef] [PubMed]

74. Martin, P.R. Stress and Primary Headache: Review of the Research and Clinical Management. Curr. Pain Headache Rep. 2016, 20, 1-8. [CrossRef] [PubMed]

75. Warren, M.P.; Fried, J.L. Temporomandibular Disorders and Hormones in Women. Cells Tissues Organs 2001, 169, 187-192. [CrossRef] [PubMed]

76. Huang, J.Z.; Han, M.F.; Luo, T.D.; Ren, A.K.; Zhou, X.P. Mental health survey of 230 medical staff in a tertiary infectious disease hospital for COVID-19. Zhonghua Lao Dong Wei Sheng Zhi Ye Bing Za Zhi 2020, 38, 192-1951.

77. Özdin, S.; Özdin, S.B. Levels and predictors of anxiety, depression and health anxiety during COVID-19 pandemic in Turkish society: The importance of gender. Int. J. Soc. Psychiatry. 2020, 66, 504-511. [CrossRef]

78. Seo, D.; Ahluwalia, A.; Potenza, M.N.; Sinha, R. Gender differences in neural correlates of stress-induced anxiety. J. Neurosci. Res. 2017, 95, 115-125. [CrossRef] [PubMed]

79. Wang, Y.; Di, Y.; Ye, J.; Wei, W. Study on the public psychological states and its related factors during the outbreak of coronavirus disease 2019 (COVID-19) in some regions of China. Psychol. Health Med. 2021, 26, 13-22. [CrossRef] [PubMed]

80. Liu, N.; Zhang, F.; Wei, C.; Jia, Y.; Shang, Z.; Sun, L.; Wu, L.; Sun, Z.; Zhou, Y.; Wang, Y.; et al. Prevalence and predictors of PTSS during COVID-19 outbreak in China hardest-hit areas: Gender differences matter. Psychiatry Res. 2020, 287, 112921. [CrossRef]

81. Babicka-Wirkus, A.; Wirkus, L.; Stasiak, K.; Kozłowski, P. University students' strategies of coping with stress during the coronavirus pandemic: Data from Poland. PLOS ONE 2021, 16, e0255041. [CrossRef]

82. Cho, S.; Jeon, G.S. Gender Differences in Type D Personality and Mental Health among Korean College Entrants. Korean J. Stress Res. 2018, 26, 133. [CrossRef] 